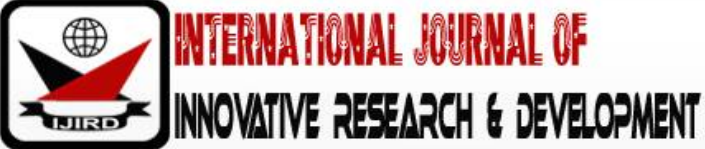

ISSN 2278 - 0211 (Online)

\section{Students' Perspectives on Courses Evaluation in Universities: A Case of Archbishop Mihayo University College of Tabora (Amucta), Tanzania}

\author{
Dr. Apolinary Kaswala Ndasi \\ Lecturer, Department of Education Foundations, \\ Archbishop Mihayo University College of Tabora (AMUCTA), Tanzania
}

\begin{abstract}
:
The study investigated the students' perspectives on courses evaluation at AMUCTA as a case among universities. The low rate of students' participation in courses evaluation had raised concerns among some academic staff on the university's self-evaluation and quality assurance mechanism at the institution. However, the factors for the issues of concern among the staff were not known besides the fact that courses evaluation was a compulsory exercise in the institution and no known study had been done on the matter. The study employed concurrent mixed methods research design. Four research questions and hypotheses guided the study. Semi-structured questionnaires were administered to 228 third year students who were randomly selected. Quantitative data were analysed through descriptive and inferential statistics using Statistical Package for Social Sciences (SPSS) version 22. Qualitative data were analyzed through thematic approach by identification of themes. The findings indicated that the students saw courses evaluation as an important exercise although they had low morale to take part in the exercise. Furthermore, there had been no feedback given to the students from the evaluation reports nor any measures taken on what they always proposed. Students' demographic characteristics had no statistic significant effect on their rating of the effectiveness of and satisfaction with courses evaluation. The study concludes that the factors for the low rate of students' participation in courses evaluation stemmed from the AMUCTA environment. Their concerns about the impact of courses evaluation in their studies made them respond to the questionnaires at low rate though the alternative solutions that they provided were viable. Hence, the study recommends to the management to revisit the practice of courses evaluation at the institution and address students' concerns.
\end{abstract}

Keywords: Assessment, evaluation, effectiveness, perspectives, quality assurance

\section{Introduction: Background to the Problem}

Ensuring quality in education in all institutions is of utmost importance for quality delivery of services. One of the means for enhancing quality of education in higher learning institutions is through conducting courses evaluation (Nabaho, Aguti \& Oonyu 2017). Courses evaluation in universities and colleges are meant for institutional internal selfassessment and evaluation for improving teaching and learning. Santiago \& Benavides (2009) in Mudavanhu (2015, p. 99) argue that meaningful evaluation involves an accurate appraisal of the effectiveness of teaching, its strengths and areas for development, followed by feedback, coaching and support for professional development. In this view, Archibong and Nja (2011) point out that students are the most qualified resource to report on the extent to which the learning experience is productive, informative, satisfying or worthwhile and also to provide reassurance that the evaluations exercise contributes to quality services in the education process. This implies that the students are expected to play a noble role in ensuring quality education in universities by assessing the courses and their lecturers' performance in teaching and learning. While this role is that important, it was yet to be established whether the students realised its importance and played their evaluative role at their institution.

Course evaluation is one of the core aspects of self- assessment of teaching and learning processes. As the content and lecturers' performance are crucial components of the inputs on the education process, their evaluation helps to determine the quality of teaching and learning. In this view, Imansari and Sutadji (2017) identify the input, dimension as learning achievements, curriculum structure, qualified lecturer, and course outline as important aspects of the evaluation exercise. This can be ascertained by studies which have indicated that, when both students and lecturers cooperate in the assessment of courses offered, there is an assurance that the effectiveness of teaching and learning is are enhanced (Kahramanoglu, Aslan, Yilmaz, Odabas, Tekerek and Oflaz, 2018).

In this regard, the Inter-University Council of East Africa (IUCEA) articulates that self-assessment is important for ascertaining quality; so, it is a demand driven by the importance of examining quality in a structural manner (IUCEA, 2010, No 1.5 in SAUT 2017). In this line, the Tanzania Commission for Universities (TCU) provides that each university should have effective quality assessment tools (TCU, 2014). 
This extends to the right of students to be involved in all the matters that affect their academic life. In this view, the Universities Act stipulates that, 'each university shall ensure that students continuously exercise their right to contribute to the making of institutional policy and other instruments generally affecting their social or academic affairs' (URT, 2013, No. 56 part 1, a). As teaching and learning do affect students' academic affairs, they have the right to see to it that assessment procedures are in favour of this right. It is unclear whether AMUCTA students are aware of this right and duty of ensuring that they get quality education that they deserve. This should translate to their active participation in courses evaluations although the contrary is being experienced at the institution. This begs the question as to why this scenario is prevailing.

However, the objectivity of students' courses evaluation has been controversial in some cases. Husbands (1997) noted that some students evaluate the lecturers differently even when they use the same mode of delivery such as lecturing. Hence, there are variations in rating the teaching and learning among students in different courses in which the lecture method was predominantly employed during the teaching and learning processes. Probably, the nature of some courses was a factor or some instructors employed lecture method differently. Nevertheless, whether the same variations applied in courses evaluation at AMUCTA was unknown.

In keeping with IUCEA (2010) directive that students should be involved in the self-assessment exercise, the Saint Augustine University of Tanzania (SAUT), including AMUCTA, uses courses evaluation forms that are filled in by the students at the end of the teaching of the courses in every semester. The SAUT Quality Assurance Manual provides that 'the students will have to evaluate lecturers using students' course evaluations forms' (SAUT, 2017, part 6.3.1 D). This is part of SAUT's internal quality assurance mechanisms for monitoring and assessing teaching and learning. The outcome of students' courses evaluation is expected to be a driving force for positive response of the faculty to improve the teaching and learning in the SAUT and her affiliate constituent colleges and centres in general.

However, experience indicates that AMUCTA students do exhibit little interests in participating in the filling of the course's evaluation forms. The exercise was becoming a challenge as the team of quality assurance were struggling to get students to fill in the forms. Some students ran away whenever they saw a lecturer going in the lecture halls with the evaluation forms. Intriguingly, some instructors forced the students to fill in the evaluation's forms. As a result, some forms were returned blank and even those that were filled had many gaps of unanswered questions. As a result, there was a low participation rate as measured by $10 \%$ of the minimum sample of a class size. There were some variations in participation rate in courses evaluation even from the same class in different courses (AMUCTA, 2016, 2017 and 2019). The validity of the courses evaluation at the university college was, therefore, questionable.

The issue of students' indifference in the exercise of courses evaluation was confirmed by the records in the evaluation reports. The reports indicated inconsistency in the students' participation in courses evaluation. From the sampled evaluated courses, one can determine the level of students' participation rate in the evaluation exercise in the three preceding academic years of 2015/2016; 2016/2017 and 2018/2019. The measurement of participation rate was based on the number of students who took the courses. Examinations attendance was preferred to the lists of registered students in the academic years as not all the registered candidates attended the courses for varied reasons. Assumption was that the students who sat the examinations in different courses had an opportunity to take part in courses evaluation after they had completed their coursework. Tables 1, 2 and 3 provide summaries of the level of participation of students in courses evaluation from the sampled courses and their corresponding academic years.

\begin{tabular}{|c|c|c|c|c|c|}
\hline S/No & Course Code & $\begin{array}{c}\text { Exam } \\
\text { Attendance }\end{array}$ & $\begin{array}{c}\text { Evaluation } \\
\text { Participants }\end{array}$ & $\begin{array}{c}\text { Observed } \\
\text { Percentage }\end{array}$ & $\begin{array}{c}\text { Expected } \\
\text { Percentage }\end{array}$ \\
\hline 1 & EP 100 & 323 & 37 & 11.46 & 10 \\
\hline 2 & CT 102 & 252 & 68 & 26.00 & 10 \\
\hline 3 & EP 300 & 727 & 37 & 5.09 & 10 \\
\hline 4 & EA 302 & 726 & 38 & 5.23 & 10 \\
\hline 5 & LIT 301 & 66 & 8 & 12.12 & 10 \\
\hline 6 & LL 317 & 194 & 8 & 4.12 & 10 \\
\hline 7 & RM 200 & 244 & 7 & 2.87 & 10 \\
\hline
\end{tabular}

Table 1: Students' Participation Rate in Courses Evaluation in the First Semester for 2015/2016 Year

Data in Table 1 indicate that in the four courses, the student's participation rate was less than the expected percent $(10 \%)$ and three had more than the minimum number. The factors responsible for the variation in the participation rate, with extreme in the largest classes was not known. Whether it was easy for lecturers to solicit participation in small classes than in large ones was yet to be established. The factors for higher participation rates in EP 100, CT 102 and LIT 301 than the SAUT recommended standard of 10\% remained covered (AMUCTA, 2016). A similar scenario was exhibited by the records in the academic year 2016/2017. However, there were some differences as the participation declined more than in the preceding academic year. The data on the stated rate are summarized in Table 2. 


\begin{tabular}{|c|c|c|c|c|c|}
\hline S/No & Course Code & Exam attendance & $\begin{array}{c}\text { Evaluation } \\
\text { Participants }\end{array}$ & $\begin{array}{c}\text { Observed } \\
\text { Percentage }\end{array}$ & $\begin{array}{c}\text { Expected } \\
\text { Percentage }\end{array}$ \\
\hline 1 & CT 102 & 244 & 41 & 16.80 & 10 \\
\hline 2 & RM 200 & 244 & 7 & 2.87 & 10 \\
\hline 3 & SN 111 & 180 & 28 & 15.56 & 10 \\
\hline 4 & SN 110 & 184 & 12 & 6.52 & 10 \\
\hline 5 & SN 212 & 119 & 9 & 7.56 & 10 \\
\hline 6 & EP 101 & 685 & 11 & 1.61 & 10 \\
\hline 7 & EA 302 & 350 & 24 & 6.85 & 10 \\
\hline 8 & EP 300 & 349 & 14 & 4.01 & 10 \\
\hline
\end{tabular}

Table 2: Students' Participation Rate in Courses Evaluation for the Year 2016/2017 Semester I

The data in Table 2 reveal that even some of the courses with small number of students registered a low rate of participation in the courses evaluation when compared with the 2015/2016 academic year. Further, the data showed that courses with many students had a persistent participation rate of less than the $10 \%$ required standard. Further observation was made on the records of the 2018/2019 academic year. The data in the year are summarised in Table 3.

\begin{tabular}{|c|c|c|c|c|c|}
\hline S/No & Course Code & Exam attendance & $\begin{array}{c}\text { Evaluation } \\
\text { Participants }\end{array}$ & $\begin{array}{c}\text { Observed } \\
\text { Percentage }\end{array}$ & $\begin{array}{c}\text { Expected } \\
\text { Percentage }\end{array}$ \\
\hline 1 & EP 300 & 773 & 10 & 1.29 & 10 \\
\hline 2 & EP 302 & 773 & 44 & 5.69 & 10 \\
\hline 3 & SW 312 & 438 & 45 & 10.27 & 10 \\
\hline 4 & SW 324 & 433 & 39 & 9.01 & 10 \\
\hline 5 & WS 325 & 436 & 48 & 11.01 & 10 \\
\hline 6 & HI 360 & 336 & 24 & 7.14 & 10 \\
\hline 7 & HI 304 & 339 & 25 & 7.37 & 10 \\
\hline 8 & EA 301 & 768 & 20 & 2.60 & 10 \\
\hline 9 & SE 311 & 767 & 12 & 2.61 & 10 \\
\hline 10 & LL 314 & 131 & 9.16 & 10 \\
\hline
\end{tabular}

Table 3: Students' Participation Rate in Courses Evaluation for 2018/2019 Academic Year

The data in Table 3 confirm that the trend of participation rate was low. It declined over time from one academic year to the next (AMUCTA, 2016, 2017 \& 2019). What was more intriguing was the fact that the same students participated highly in some general courses and lowly in the others. The cases of EP 300 and EP 302 confirm this observation. However, the factors responsible for this variation remained unknown. The general decking trend in students' participation in courses evaluation threatened the effectiveness of self-evaluation and the quality of education offered at AMUCTA. It was, for instance, unclear why the students exhibited little or no interest at all in the evaluation exercise. Whether students attached any value to the exercise was, thus, unknown. It was also unclear whether students understood the role of courses evaluation or were that it was a mandatory exercise as per the SAUT provision. Whether their valuation was honest and objective was yet to be ascertained.

This situation invited questions on whether the self-assessment made by the students at AMUCTA was objective and relevant for meaningful judgement and the measures that could be taken. By way of extension, effective selfassessment and evaluation in this regard was endangered and quality assurance became vulnerable to negative criticism. Consequently, the academic performance at the university college became wanting.

Various factors can affect students' evaluation of courses. They range from their perceptions, expectations and understanding among others. When students believe that their views and opinions on evaluation can be considered by the instructors and the university management at large, they actively participate and respond to the evaluation surveys (Chapman and Joines, 2017). Yin Fah and Osman (2011) reported that courses and lecturers' characteristics affected students' evaluation of teaching in universities. The study confirmed that lecturer overall teaching performance ratings were correlated with course characteristics and lecturer characteristics. Whether these applied to AMUCTA students' course evaluation remained unclear. Consequently, there was need to find out the factors responsible for this strange behaviour from the AMUCTA students and make relevant interventions before it became a chronic phenomenon and to scale up quality assurance at AMUCTA through meaningful self-evaluation.

\subsection{Statement of the Problem}

While self-assessment that involves students is important for quality education in universities (IUCEA, 2010), the AMUCTA students exhibited low morale to actively take part in the exercise which was done through course evaluation. This trend was noticed at the university college yet there were no known reasons to account for it and it seemed to worsen with the passage of time from one academic year to another (AMUCTA, 2016, 2017 \& 2019). This raised concerns among some lecturers as it seemed to weaken the effectiveness of the quality assurance mechanism. Some lecturers felt unmotivated to get students for the exercise that seemed not effective. Thus, the objectivity of selfassessment and quality assurance at AMUCTA, through courses evaluation, had become questionable. The policy of evaluating courses and the opportunity provided to students seemed to bear no targeted results. This precarious situation 
risked taking appropriate measures for improving the teaching and learning at the university college; hence, the need to alley them lest they negatively affect the quality of education. As there was no known study that had addressed this issue, the knowledge gap posed a challenge of intervention measures to alley the negative impact of the situation and improve quality assurance practice. This study, therefore, examined the students' perspectives on courses evaluation at AMUCTA.

\subsection{Research Questions}

- Why do students at AMUCTA participate at low rate in courses evaluation?

- What are the students' attitudes towards courses evaluation practice at AMUCTA?

- Do students see AMUCTA courses evaluation practice worthwhile?

- Which courses evaluation strategies would students prefer to the use of evaluation forms?

\subsection{Research Hypotheses}

- There is no significant difference in the students' mean rating scores of the effectiveness of courses evaluation at AMUCTA based on programme of study.

- $\quad$ There is no significant difference in the BAED students' mean scores on their satisfaction with courses evaluation at AMUCTA when compared with those taking BEDSN.

- There is no significant difference in the students' mean rating scores of the effectiveness of courses evaluation at AMUCTA based on sex, age and programme of study.

- There is no significant difference in the students' mean rating scores on their satisfaction with courses evaluation at AMUCTA when comparing FEDU with FASSC.

\subsection{Significance of the Study}

The study sheds some light on the status of courses evaluation with respect to students' contribution to selfevaluation practices. It reveals the views and opinions of students on how to improve courses evaluation and subsequently self-assessment at AMUCTA. As such, it is an informative study whose findings could be used by the AMUCTA management to make informed decisions on how to make effective and efficient evaluation of courses and improve the teaching and learning at the institution. This could enhance quality education at the institution.

\subsection{Scope of the Study}

The study was carried out at AMUCTA in Tabora, Tanzania due to experience of challenges in the course's evaluation at the institution. Only third year undergraduate students were included in the study as it was the only available group at the time of this study. The study was delimited on students' perceptions and opinions on the effectiveness of courses evaluation and their suggestions on what could be alternative means for courses evaluation.

\subsection{Theoretical Framework}

The research was grounded on the Fifty- Fifty Rule (Theory) that was developed by Adair (2006). The theory stipulates that fifty (50) per cent of our motivation comes from within us and fifty (50) per cent from without us (from our environment, especially the people around us). The fifty per cent of human incentive to behave in some manner or to perform a task comes from within a person and fifty per cent comes from his or her environment, especially from the leadership that a person encounter. Though the theory is not mathematical, that is, the different proportions in the equation are not exactly fifty - fifty, yet it stands that human motivation has two driving forces, those within and the ones outside the person. However, the factors that are outside the individual are beyond control or influence by one. It follows, therefore, that the extent to which one can motivate another is limited much as the other half percent is dependent on the individual's intrinsic level of motivation and only half of motivation stems from the environment.

The theory suited the explanation of the low level of students' participation in the evaluation of courses. It was appropriate to measure whether the low level of participation stemmed from the students or the environment (administration and instructors' behaviour) within the university college. Though the theory is subjective as it is not mathematical of the two sides and, hence, weak in this regard, it was relevant to guide the study to establish which part could exert more influence on the students' behaviour. The strength of the theory in establishing this situation made it justifiable for its application in this study.

\subsection{Conceptual Framework}

In this study, the three categories of variables were measured as they related on students' response level on courses evaluation. The following figure presents a conceptual framework of the study. 


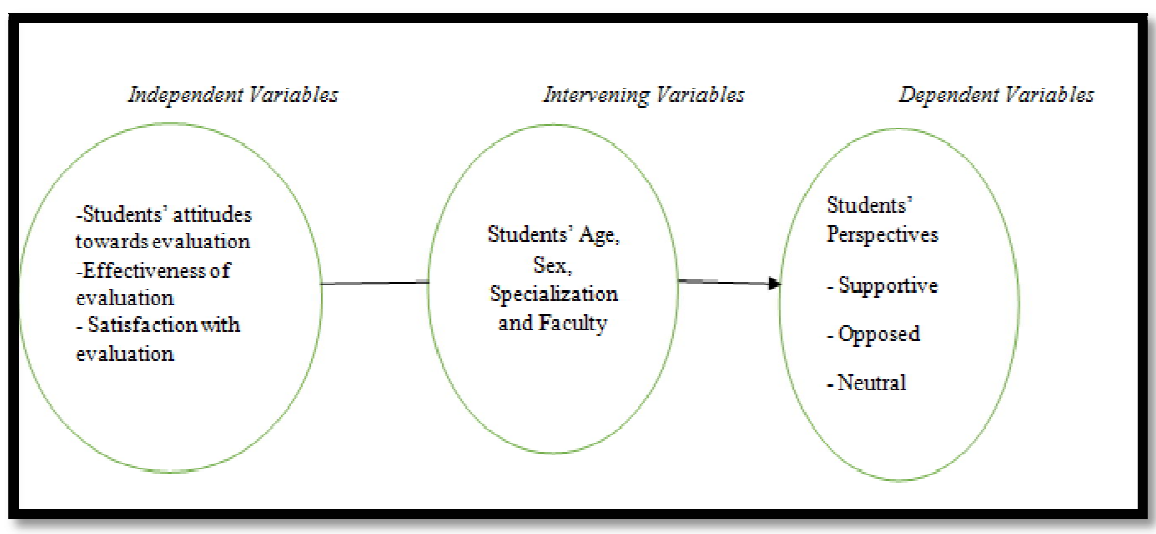

Figure 1: Conceptual Framework

As the diagram indicates, students' attitudes towards courses evaluation, its effectiveness and their satisfaction with the exercise could influence their perspectives on the exercise. The perspectives could be supportive to the practice, neutral or opposed to it. Students' age, sex, programme of study (specialization) and faculty they belonged to were conceived as intervening variables that could influence the way students perceived the practice of courses evaluation as the dependent variable (perspectives). Conversely, the intervening variables could influence the independent variables as they might affect the students' scores on attitudes items, the effectiveness and their satisfaction with the course's evaluation mechanism. These were considered important variables to be measured in this study and were measured through testing of the hypotheses.

\subsection{Operational Definition of Terms}

- In this study, 'business students' applies to those students in bachelors of Business Administration, Sociology, Laws and Public Relation and Marketing programmes.

- Low rate of participation in this study refers to less than $75 \%$ participation.

\section{Review of Related Literature}

The review of related literature is based on factors for participation in courses evaluation, students' attitudes towards courses evaluation, importance of courses evaluation and approaches to enhancing effective courses evaluation.

\subsection{Factors for Students' Participation in Courses Evaluation}

Students' expectations on the outcome of the courses evaluation do count in their level of participation and response rate to the evaluation exercise. Chapman and Joines (2017) found that when instructors show students that they care about evaluations, response rates tend to be higher. Their study indicated that the instructors used various strategies to motivate students to evaluate courses. They included talking about the importance of evaluation in their classes, creating an environment of mutual respect in the classroom and telling their students how they used evaluation results to modify their courses.

Based on these findings, it was interesting to know whether the instructors at AMUCTA did encourage the students to actively take part in the evaluation of courses.

While students' courses evaluation is important since it can be influenced by grades or pass rates among students. Evaluation scores can rely on the grades given by lecturers. Chen, Wang \& Yang (2017) analyzed the correlations between teaching evaluation scores, students' final grades and course fail rates in one university in Taiwan to establish whether students' final scores and course fail rates were important predictors of teaching evaluation scores. Both students' surveys and database of grades and evaluation scores were used to generate the data. The study uncovered that there was a positive correlation between teaching evaluation scores and students' final grades, and a negative correlation between teaching evaluation scores and course fail rates. The student's final grades and course fail rates were predictors of teaching evaluation scores. While the study informed on teacher characteristics and students' scores on evaluation, it did not address the rate of students' participation and their views on courses evaluation. This remains unanswered question as a knowledge gap.

The online courses evaluation has been a challenge for varied reasons. Guder and Malliaris (2013) investigated, through survey, the online course evaluations response rates and disclosed that the reasons for students' non-response to courses evaluation included being busy and that the surveys were too long. Therefore, the exercise did not matter for them; hence, they forgot or had nothing to comment about the courses evaluated. Despite these revelations, one was not sure if such reasons could apply to AMUCTA students as the evaluation was done on paper as opposed to the one through online means. Also, there was no evidence whether the evaluation done on paper could make a difference in students' responses when compared with the online one.

Sometime self- evaluation in universities can become ineffective for varied reasons. Archibong and Nja (2011) found that teaching effectiveness was grossly ignored in the lecturer appraisal process. This might apply to AMUCTA evaluation practice as students do not show interests in filing in the evaluation forms for the same. Yet this remained to be established. Above all the study was based on the general evaluation of teaching in universities, not specifically on 
students' perspectives on the practice. The instrument that was used in this survey study was only a five-point Likert scale that gave no room for detailed additional responses. The participants' views and opinions were missed in the study.

Similarly, the mechanism used in self-evaluation in universities is significant in the practice. It can contribute to efficiency or become inhibitive of active participation of stakeholders such as students. Groen and Herry (2017) established that the use of online course evaluation resulted in decrease of participation rate of students by $12 \%$ to $15 \%$ when compared with paper-based evaluation at the University of Ottawa. Yet, no significant difference in the evaluation scores were observed. Both the academic staff and students had positive perception on the online system. However, they suggested that the university should maintain in-class period evaluation besides the electronic course evaluations. Whether the students had alternative courses evaluation system at AMUCTA was yet to be seen.

\subsection{Perspectives on Courses Evaluation}

Several factors do influence perspectives on self-assessment in universities. One of them is the lecturers' characteristics. Atek, Salim, Halim, Jusoh \& Yusuf (2015) found that male lecturers valued students' evaluation of teaching higher than their female colleagues. Though statistically insignificant, lecturers of both genders found SET more useful for formative than summative functions. The study informs on lecturers' aspect, but not on students. It remains silent on the students' views on SET. That bother genders valued formative rather than summative evaluation, triggers the intellect to speculate as to whether AMUCTA students can make a difference as the course evaluation is essentially summative. Probably, the gender of the students could make a different influence in their perspectives on the evaluations. This nudging question needs to be answered by establishing relevant facts.

Furthermore, the instructors' competence and performance determine the evaluation results. Mudavanhu (2015) found that students' evaluation of lecturers showed that the ones in education and the others without educational background differed in their modes of delivery. This qualitative study only reported that the students evaluated their lecturers in supervision of teaching practice but not on whether there was any challenge with regards to students' active participation in the evaluation exercise.

Apart from lecturers' characteristics, students' features can determine the evaluation of courses. Students' variables such as age, gender, employment and family status among others do influence the way they assess teaching and learning. Thawabieh (2017) reported that when students evaluated a faculty, the results indicated that there were statistically significant differences in students' evaluation based on gender, college and expected grade in the course. That means the participants' characteristics had bearings on the way they saw their lecturers' performance. Besides informing on the level of faculty evaluation and the relationship of students' variables (gender, expected grade, and college on students' evaluation) and the scores, it remains unknown on the values attached to courses evaluation by the students. The study was delimited to the way students evaluated their faculty, not on their interests to take part in courses evaluation.

Experience with the course can influence students' perspectives on its evaluation. Royal \& Stockdale (2015) investigated graduate students' responses to teacher/course evaluations to determine whether students' responses were inherently biased against faculty members who taught quantitative methods courses at the College of Veterinary Medicine, North Carolina State University. The study used item response theory and differential item functioning techniques for data analysis. The instrument contained 19 items that were divided among three categories: course; instructor and learning outcomes items. A five-point rating scale was provided, with the response options Strongly Disagree, Disagree, Agree, Strongly Agree, and Not Applicable. Results indicated that students in non-methods courses preferred the structure of quantitative courses but tended to be more critical of quantitative methods instructors. Whether students were motivated and responded highly and they had positive outlook to the exercise remained concealed.

The nature of classes determines students' perspectives and they act accordingly in courses evaluation. In their cross-case study, Turley and Graham (2019) explored on whether differences existed between two online course models by investigating the results of a student end-of-course evaluation survey and teacher communication logs in two online high school courses in the USA. The study involved high school students enrolled in secondary level math and English online courses. It was found that the interactive course had a statistically significantly high rating in some dimensions of the evaluation. Teacher's communication logs disclosed a high teacher time investment in the more interactive courses. Though the authors reported to have encouraged students to participate in courses evaluation by making it anonymous, it remained unclear whether they were motivated. The rate of participation was also not reported.

There are cases of contrary findings on courses evaluation in universities. Some students evaluate the courses and lecturers highly while others award them low scores. Sometimes the quantitative findings are contrary to the qualitative data. In such cases, the findings become problematic. This is confirmed by Flégl, Fortoul, Švec, Brand and Vizuet Ch. (2017) whose study findings showed that students evaluated their professors (courses) positively, yet their openended responses revealed that there were challenges with courses evaluation. These are problematic findings since they are contradictory. Thus, the factors responsible for the contrary findings of study pose questions. This is confirmed by other studies such as the one conducted by Jiang, Javaad andGolab (2016) who reported that some classmates rated courses and instructors differently and some bad courses were rated highly by some students. The findings revealed further that even some poorly considered courses were rated highly by some students. The findings suggest that the objectivity of course evaluation by students can be problematic and incredible. This intriguing fact was a hypothesis which required to be tested.

In this regard, Gravestock, Greenleaf and Boggs (2008) concluded that students' evaluation of courses and teaching at universities remains a controversial issue and divisive topic. This leaves an answered question as to whether the case of AMUCTA is different from this fact. The issue of the validity of courses evaluation is central in this study which endeavoured to find out if it can be established for meaningful self-assessment at the university college. 
Courses' and students' characteristics have a bearing on both their attitudes and course evaluation. Johnson, Narayanan and Sawaya (2013) evaluated course and instructor demographic data to determine whether the characteristics affected students' evaluation of teaching (SET) from a large engineering college at a major public university. The data were collected over a seven-semester period that covered 3938 courses taught by 549 unique engineering lecturers. It was found that a course's characteristics such as class size, course level, and whether a course was an elective or core had statistically significant effects on SETs. Instructor characteristics of gender and academic rank affected SETs and average course grades, respectively. Average course grades were positively correlated with SETs.

\subsection{Importance of Evaluation of Courses}

Recent studies indicate that assessment and evaluation in education is an important measure of teaching and learning. One of the important components is students' assessment. Sukdee, Tornee \& Kraipetch (2017) found that one of the factors influencing key success indicators in curriculum quality assurance operation for bachelor's degree in Physical Education was the students' assessment component. This can be extended to students' evaluation of the courses. While this is crucial for quality education, AMUCTA staff witnessed the mixed reactions on the matter of course evaluation by students. It was unknown whether the students at AMUCTA saw any value of such evaluations. The study focused on factors influencing indicators in curriculum quality assurance and ignored the perspectives of students on such evaluations. The study did not further address the critical concern on students' low level of motivation in taking part in courses evaluations at the area of study.

Students' evaluation of courses helps in determining the relevance of the courses in relation to the labour market available. It works as fuelling power of the review of courses besides the improvement of teaching and learning. Okmen (2017) assessed the vocational education courses given in schools of physical education and sport and their use in the life of professionals using evaluation forms in Turkish universities. The participants were randomly selected from among the physical education and sport teachers in government and private schools in the cities of Edirne, Tekirdag, and Kirklareli of the Trakya region of Turkey. The study established that some of the courses were given low scores; hence, were not needed in their professional careers and had to be re-evaluated or eliminated from the curriculum. Additionally, the course hours and contents were to be rearranged and developed. From this study, the question that emerges is to whether the students could give the same scores. Additionally, it remains unknown whether the students were actively involved in the evaluation of the courses.

Similarly, Coetzee, Hoffmann and de Roubaix (2015) explored the content and teaching approach of research ethics education in the health science undergraduate programs at a South African university via qualitative study. The study disclosed that the content was vaguely formulated and the timing of research methodology of ethics in a fourth year of the course was not appropriate as most students could not successfully complete developing their research proposal as required. The study, consequently, recommended it to be taught at earlier stages. Besides informing on the evaluation of the courses, the study did not focus on the students' participation in the evaluation process. Only research coordinators were involved, leaving aside students' views and opinions. The study also did not focus on students' views but rather on general course evaluation. What the students thought about the practice of courses evaluation remained undisclosed.

Through courses evaluation, an institution can be informed about the effectiveness of the medium of teaching and learning. Celebi (2018) uncovered that 'Facebook' as an educational tool in 'recreational leadership course' was perceived mostly positive by students and the lecturer in Turkey. Students showed that it helped in personal, emotional, performance and cognitive development of a person. The lecturer revealed four themes namely improving the quality of class management, helping in systematic application of technology, improving the quality of education/students and learning by doing.

When students cooperate in self - assessment processes, a true picture of the teaching and learning can be portrayed. This helps decision-makers to work on informed bases. Al-Ali (2014) measured students' perceptions towards lecturers' competencies and confirmed that the lecturers stressed on some academic issues (defining courses, clarifying teaching methods to students, students' expectations, enhancing writing skills, encouraging work accuracy and recognizing students' differences) during their academic courses but neglected other important components learning (encouraging innovative thinking, building problem solving skills, time management etc.). Similarly, findings from a study by Coyne, Lee and Petrova (2017) revealed that students preferred live lectures to flipped classroom. These imply that students, in both cases, were open, keen and serious with course evaluation. Nevertheless, one is not sure whether AMUCTA students reflect the same standard in self-assessment practice through courses evaluations.

When students make objective evaluation, a true picture of teaching and learning is exhibited and possible fallacies are minimized. This is supported by a study by Culver (2010) who found that, though students rated faculty more highly when they expect higher grades in the course, this relationship was moderated significantly by the quality of teaching and learning of the course. The researchers concluded that engaging students in quality efforts in a course rather than giving them high grades would increase students' rating of faculty. The study informs us on the experience of valid evaluation of courses. However, the study was not interested on the students' perspectives, effectiveness and satisfaction with the course's evaluations.

Self-assessment and evaluation can reveal challenges and mixed feelings between lecturers and students regarding teaching and learning. Students might prefer some aspects of learning to lecturers' preference in teaching. A study by Ratanapruks, (2015) revealed that majority of students were contrary to listening assessment as they believed that they lacked the ability to do the test while one director and four teachers were in favour of the assessment. This means that there was a need to address the challenge. One may ask as to what could be the reality at AMUCTA in terms of 
students' preferences compared with the lecturers with regards to course evaluations in relation to students' participation in the exercise.

Some scholars such as Fraile and Bosch-Morell (2014) had reported on the need to ensure that courses evaluation practices by students are reliable. The study showed that, though the lecturers' performance was not affected by the number of valid questionnaires received, nonetheless, the variability of the results increased when the questionnaire decreased. That is, the measures from limited number of questionnaires tended to be less reliable. The researchers proposed to consider the lecturers' teaching history that could complement a single course evaluation result.

At times, lecturers use teaching strategies that are not student friendly to all but do it for the sake of coping with science and technology. This might make teaching and learning a challenge to the staff. In a study by Seechaliao (2015), it was established, through a survey study using questionnaires, that lecturers lacked the requisite teaching experiences in using social media in courses at Mahasarakham University in Thailand and that they were struggling to cope with the new technology. This implies that the teaching of the courses through this media was a challenge. It must have impacted negatively on the evaluation of the course accordingly. Besides informing on the experience of lecturers, the study did not directly evaluate the course in the light of students' views but was delimited on lecturers alone. Therefore, the students' perspectives on the same remained concealed.

\subsection{Approaches to Improving Participation Rate in Courses Evaluation}

Different scholars have come up with various strategies to improve students' participation rate in courses evaluation. One of the approaches is to motivate students to make courses evaluations. Encouraging students to participate and respond to evaluation questions was seen to work and, in some cases, making it successful. Njoku (2018) conducted a pre- and post-survey (longitudinally) on line evaluation to assess the effect of course content on students' health disparities knowledge, attitudes and beliefs and to assess instructor performance for two courses at a rural Midwestern U.S. university (Ferris State University). A five-point Likert scale was used to collect data. It was after the faculty authority advised administrators to actively encourage students to complete evaluations in order to achieve higher response rates. The findings indicated a statistically significant increase in mean scores for survey items pre- to postsurvey. Paired t-tests of the pre- and post-survey scores exposed significant positive changes in scores for the survey questions. The study provides evidence that encouraging students to evaluate courses can scale up their participation and response. However, the findings from the study does not show their perspectives on the course's evaluation; hence, begging a question on them.

The tool for evaluation of courses is important for it to be effective in measuring the performance of the instructor as well as students' involvement. Zhao \& Gallant (2012) investigated into students' evaluation of instruction in higher education by exploring issues of validity and reliability in the USA. The study revealed that instructor effectiveness was appropriately and adequately assessed by the 10 observed variables in the questionnaire. The students' perception of instructor effectiveness was captured by nine dimensions of instruction namely organisation of course, intellectual stimulation, instructor interest in teaching, students encouraged to think for themselves, preparation of instructor, instructor helping students, learn from instructor, conducive atmosphere for learning and subject matter communicated clearly, and the overall instructor rating. This study imply that students were involved in course evaluation but it ignored their level of participation and response to the questionnaire. As such the knowledge gap on the same persisted.

\section{Methodology}

Concurrent parallel mixed methods design was employed in this study, specifically cross-sectional survey design. All the (869) third year undergraduate students were the target population of this study. Stratified sampling was applied. The students' faculties, departments and programs of study were considered as strata that differentiated them. Hence, stratified random sampling was used to select participants. The students from Kiswahili and History units were selected by rows in the tables based on their serial numbers as their sampling lists were large. Simple random sampling was employed to select participants in others units. The sample size comprised 228 students. Table 4 presents a sampling matrix of these participants.

\begin{tabular}{|c|c|c|}
\hline S/No & Specialization & Number \\
\hline 1 & Kiswahili \& History & 140 \\
\hline 2 & Geography & 35 \\
\hline 3 & Linguistics & 20 \\
\hline 4 & Literature & 20 \\
\hline 5 & BBA, BASO\& BAPRM & 08 \\
\hline 6 & LLB & 05 \\
\hline & Total & 228 \\
\hline
\end{tabular}

Table 4: Sampling Matrix

A semi-structured questionnaire was used to collect the required data. Quantitative data were analysed through descriptive statistics of frequencies and percentages and inferential statistics for hypotheses testing of independent samples $\mathrm{t}$ - test and Analysis of Variance (ANOVA). The Statistical Package for Social Sciences (SPSS) that is considered to be the most popular in social sciences (Field and Hole 2013) version 22, was used to analyse the quantitative data. 
Qualitative data such as opinions, views, perceptions, suggestions and explanations were analysed thematically by creating categories of themes, summarizations and synthesising. Different scholars such as Mugenta and Mugenda (2003), Kombo and Tromp (2006) and Gall, Gall, and Borg (2007) are in favour of this view. Quantitative data was presented through tables and qualitative data through paraphrasing, explanations and quotations.

Reliability (consistency) of the findings were ensured by method, source and instrument triangulation, the use of the same instrument to all participants and comparing the quantitative and qualitative data. Source triangulation was applied to the involvement of the students from all the programmes. Validity of the study was ensured through pilot testing the questionnaires to ten (10) students and making relevant corrections.

To meet ethical requirements, the researcher collected and analyzed the data objectively and reported what was provided by the participants. The questionnaire for data collection had instruction that covered the aspect of voluntary participation in the study. The ten students who were involved in pilot testing of the questionnaires did not participate in the real study. Additionally, the researcher obtained permission from the AMUCTA management to collect data from the students.

\section{Findings and Discussions}

\subsection{Return Rate of the Questionnaires}

The questionnaires were administered to students in all the degree programmes. Out of the 228 selected participants, 192 (84.21\%) participated in the study. The summary of the findings is presented in Table 5.

\begin{tabular}{|c|c|c|c|c|}
\hline S/No & Programme & $\begin{array}{l}\text { Instruments } \\
\text { Administered }\end{array}$ & $\begin{array}{c}\text { Instruments } \\
\text { Returned }\end{array}$ & Percentage \\
\hline 1 & Kiswahili \& History & 140 & 119 & 85 \\
\hline 2 & Geography & 35 & 31 & 88.57 \\
\hline 3 & Linguistics & 20 & 18 & 90 \\
\hline 4 & Literature & 20 & 11 & 55 \\
\hline 5 & BBA, BASO\& BAPRM & 08 & 08 & 100 \\
\hline 6 & LLB & 05 & 05 & 100 \\
\hline & Total & 228 & 192 & 86.43 \\
\hline
\end{tabular}

Table 5: Return Rate of the Questionnaires

The overall return of the instruments constituted a participation rate of $84.21 \%$ and the mean percent rate as shown in Table 5 is 86.43. This is a high rate that has been accepted for validity of studies (Babbie, 2008; Rovoi, Ponton\& Baker, 2013). The students from the programmes with the number of students that were below 10 had 100 percent of return rate and those in the programmes with many students above 10 had a participation rate above 50 percent. The possible reason could be that they had more close interaction with the instructors and were motivated to take part fully contrary to those from the programmes with higher numbers.

\subsection{Reasons for Students' Low Participation in Courses Evaluation at AMUCTA}

The study sought to find out the reasons for AMUCTA students' low level in partaking in courses evaluation. The findings of the study are summarized in Table 6.

\begin{tabular}{|c|c|c|}
\hline Reason & Frequency & Percent \\
\hline Students not informed of its importance & 72 & 37.70 \\
\hline Evaluation reports not implemented & 66 & 34.56 \\
\hline Students' fear of reaction from instructors & 21 & 10.99 \\
\hline Insufficient time & 18 & 9.42 \\
\hline Too many questions in the evaluation form are tiresome & 7 & 3.66 \\
\hline Lack of students' confidence in assessing lecturers & 4 & 2.09 \\
\hline Wrong timing of the exercise & 3 & 1.57 \\
\hline Total & 191 & 100.0 \\
\hline
\end{tabular}

Data in Table 6 indicate that one of the reasons for low interest in getting involved in the course's evaluation at AMUCT was students' giving little importance to the exercise. This was stated by 72 (37.70\%) participants. One participant stated as, 'Normally students do not need course evaluation due to their misconception on the evaluation process. They think evaluation is useless in their study and that is why most of them dislike it'. This implies that the participants perceived the exercise to be less important; hence, were not motivated to take part in it.

The other reason indicated by students was that the evaluation results were not implemented by the AMUCTA management. This was reported by 66 (34.56\%) participants. One participant wrote, '...because the organization does not consider or work upon the opinions and advice given by students during evaluation'. Another participant retorted, 'Some challenges identified by students on previous forms are not taken into consideration and they do not see any changes from 
course evaluation'. The other participant remarked, '... because it is superficial to them'. Another responded, 'We do not see the feedback of course evaluation'. These responses indicated clearly that the students were not satisfied with the exercise and role of courses evaluation based on their experience that their views were not considered by the management.

Some students feared the reaction that could emanate from their instructors on the course's evaluation reports. This was indicated by 21 (10.99\%) participants. This indicated that the students had no trust in their instructors. They believed that courses evaluation that touched on assessing the way the lectures were being conducted would affect the students. This made some students to play safe by not getting involved in the evaluation of the courses. This implies that there was no sincerity and objectivity in responses provided during the exercise. Other $18(9.42 \%)$ participants gave the reason that some students did not participate in the course's evaluation due to time constraint. One responded as,

Most of the AMUCTA students do not like to be involved in filling in the course evaluation forms because of time and even when they fill in these evaluation forms they do not get or see the feedback (solving students' problems) on their suggestion; hence, that is why most students just fill the forms for the sake of doing it. Furthermore, the language that is used in the course evaluation form makes most of the students get too bored to fill it.

This means that the students were busy with other matters that hindered them from taking part in courses evaluation. They were also challenged by the difficult language used in the evaluation forms. As a result of language barrier, the course evaluation forms became a hindrance to students' participation in courses evaluation at AMUCTA.The other reason was that the evaluation had too many questions that seemed too demanding to be filled in by some students. This had a frequency of 7 (3.66\%). This gives the impression that the evaluation forms were not user-friendly to students.

Four $(2.09 \%)$ participants stated that students lacked confidence to assess their lecturers. One participant stated, 'The students lack ability of evaluation and some are unaware of the course contents'. Hence, there was a weakness on the part of some students in that they were not sure of what to evaluate.

Three $(1.59 \%)$ participants responded that the timing of the exercise was wrong. They explained that it was done during the lecture sessions and close to the end of the courses and so it could not serve its purpose to them. One of the students retorted, 'As it occurs at the end of the semester, students believe it is just nonsense. Another stated, 'It is useless and does not improve teaching and learning'. This carries the impression that the participants thought it could be meaningful if it was done from the beginning to the end like the way continuous assessment was being conducted.

The fact that the AMUCTA students could not see the importance of course evaluation has many implications. Since majority of the participants were in the education programme, Bachelor of Arts with Education (BAED) and Bachelor of Education in Special Needs education (BEDSN), they were expected to be more informed of the importance of courses evaluation and respond highly to the exercise as they were taught about assessment and evaluation. However, more than a third of the participants saw no importance of the evaluations. Probably, this was amplified by the second reason that the evaluations were not being implemented or no feedback was given to the students. Further, it could be that the lecturers did not elaborate the importance of courses evaluation to students.

That the evaluation form had too many questions and with difficult language could have been the reason for students' position that there was no sufficient time. Probably, English language was a challenge to some students. It could also be the reason that most open-ended questions in the evaluation forms were left blank by some students (AMUCTA, 2016, 2017 and 2019). Some studies have also reported on the issue of the forms having many questions that discouraged high response from students.

The findings are echoed by other scholars. For instance, the matter of the importance of feedback from the evaluations is emphasised by Santiago \& Benavides (2009) in Mudavanhu (2015). Since evaluation is meant for improvement of teaching and learning, its reports and recommendations must be implemented for it to achieve its objective. If not, then its findings and recommendations become inconsequential. Therefore, the students were discouraged to respond to the evaluation forms on this account. Similarly, implementation of the evaluation report has been underscored by scholars such as Chapman and Joines (2017) and Archbong and Nja (2011). Even the instrument factor for response rate was reported by Fraile and Bosch-Morell (2014). The findings are, therefore, relevant and theoretically compelling for consideration.

Furthermore, that some students feared the reaction from the lecturers as one of the factors for low response to participation in filling in the evaluation forms suggests that there were challenges of mutual respect between some students and their lecturers. Probably, it was the reason for many students not answering all questions in the evaluation forms. This implies that the evaluation was not truthful or objective on the part of some students. This also reflects the lack of encouragement from lecturers. This is contrary to the expected role of students in the evaluation of courses as emphasized by scholars such as Kahramanoglu, Aslan, Yilmaz, Odabas, Tekerek and Oflaz (2018) and Sukdee, Tornee \& Kraipetch (2017). This can be seen to demotivate students' participation in courses evaluation and failing to enhance the quality assurance mechanism. This implies that there is need to ensure that the evaluation exercise is done confidentially to rid the students of their fear and enable them make objective evaluation. Confidentiality in course evaluation has been insisted by scholars such as Nyabero (2016). Building it among the students could scale up their participation rate in courses evaluation.

While other lecturers encourage students to evaluate the courses (Chapman and Joines, 2017), the findings of this study imply the contrary owing to the fact that some lecturers were a threat to the evaluation exercise to an extent that students feared to evaluate them and their courses. This extends to lack of confidence to evaluate the instructors. Thus, it was a hindrance to students' active involvement in the process of courses evaluation. This becomes contrary to the SAUT Quality Assurance Manual which provides that the students will have to evaluate lecturers using students' course evaluations (SAUT, 2017, part 6.3.1 D). As such, the findings have policy implications on the quality of teaching and 
courses offered at the institution. Further, the findings imply that the factors responsible for students' low rate of participation in courses evaluation were mainly environmental-based (i.e. administration and the questionnaires).

Lack of students' confidence to evaluate the staff could emanate from both sides, the students and staff that is from within or without the participants. Adair's (2006) rule or theory of fifty - fifty applied less as only one-side factors of students' lack of confidence to evaluate their instructors could apply to both groups. The rest of the factors most likely stemmed from the environment as they were related to administration, instructor characteristics and the nature of the evaluation questionnaires, hence a demotivation emanating from outside the students.

\subsection{Attitudes of Students towards Courses Evaluation at AMUCTA}

The second question sought to explore the attitudes of students towards courses evaluation. The underlying assumption of this question was that the attitudes of participants could influence their participation in the course's evaluation exercise. It was assumed also that the students were aware of their roles in the course's evaluation exercise.

A five-point Likert scale of ten (10) attitude items was used to explore the students' attitudes. The participants were asked to indicate on the scale whether they Strongly Agreed (SA), Agreed (A), Undecided (U), Disagreed (D) or Strongly Disagreed (SD) with the attitude aspect by ticking in the relevant box in the questionnaire. The scores were arranged as follows: $\mathrm{SA}=5, \mathrm{~A}=4, \mathrm{U}=3, \mathrm{D}=2$ and $\mathrm{SD}=1$. The negative statements were reversed in the scoring process as recommended by scholars such as Field (2013).

The attitude aspects include the following: Courses evaluation by students is very important, I am always motivated to fill in the course evaluation forms, all students at AMUCTA should fill in the courses evaluation forms, the evaluation of courses improves teaching and learning at AMUCTA, courses evaluation improves quality assurance mechanism, courses evaluation at AMUCTA is a useless exercise, to me courses evaluation at AMUCTA is boring, courses evaluation at AMUCTA is a waste of time, courses evaluation at AMUCTA is superficial and AMUCTA should stop courses evaluation by students. The responses on the items on students' attitude are presented in Table 7.

\begin{tabular}{|c|c|c|c|c|c|c|}
\hline S/N & Attitude Aspect & SA & A & U & D & SD \\
\cline { 3 - 6 } & F & F(\%) & $\mathbf{F ( \% )}$ & $\mathbf{F ( \% )}$ & $\mathbf{F ( \% )}$ & $\mathbf{F ( \% )}$ \\
\hline 1 & $\begin{array}{c}\text { Courses evaluation by } \\
\text { students is very important }\end{array}$ & $132(70.6)$ & $29(15.5)$ & $4(2.1)$ & $15(8.0)$ & $7(3.7)$ \\
\hline 2 & $\begin{array}{c}\text { I am always motivated to fill } \\
\text { in the course evaluation } \\
\text { forms }\end{array}$ & $61(31.9)$ & $76(39.8)$ & $18(9.4)$ & $27(14.1)$ & $9(4.7)$ \\
\hline 3 & $\begin{array}{c}\text { All students at AMUCTA } \\
\text { should fill in evaluation } \\
\text { forms }\end{array}$ & $53(27.7)$ & $51(26.7)$ & $37(19.4)$ & $26(13.6)$ & $22(11.5)$ \\
\hline 4 & $\begin{array}{c}\text { The evaluation improves } \\
\text { teaching and learning at } \\
\text { AMUCTA }\end{array}$ & $94(49.0)$ & $37(19.3)$ & $24(12.5)$ & $13(6.8)$ & $24(12.5)$ \\
\hline 5 & $\begin{array}{c}\text { Courses evaluation improves } \\
\text { quality assurance } \\
\text { mechanism }\end{array}$ & $67(34.9)$ & $53(27.6)$ & $32(16.7)$ & $19(9.9)$ & $17(8.9)$ \\
\hline 6 & $\begin{array}{c}\text { Courses evaluation at } \\
\text { AMUCTA is a useless exercise }\end{array}$ & $31(14.6)$ & $17(9.0)$ & $21(11.1)$ & $37(19.6)$ & $83(43.9)$ \\
\hline 7 & $\begin{array}{c}\text { To me courses evaluation at } \\
\text { AMUCTA is boring }\end{array}$ & $26(13.9)$ & $22(11.8)$ & $21(11.2)$ & $38(20.3)$ & $80(42.8)$ \\
\hline 8 & $\begin{array}{c}\text { Courses evaluation at } \\
\text { AMUCTA is a waste of time }\end{array}$ & $19(9.9)$ & $18(9.4)$ & $25(13.1)$ & $42(22.0)$ & $85(45.5)$ \\
\hline 9 & $\begin{array}{c}\text { Courses evaluation at } \\
\text { AMUCTA is superficial }\end{array}$ & $27(14.1)$ & $34(17.8)$ & $63(33.0)$ & $37(19.4)$ & $27(14.1)$ \\
\hline 10 & $\begin{array}{c}\text { AMUCTA should stop } \\
\text { courses evaluation by } \\
\text { students }\end{array}$ & $19(10.0)$ & $21(11.1)$ & $17(8.9)$ & $32(16.8)$ & $101(53.2)$ \\
\hline
\end{tabular}

Table 7: Frequency Distribution of Students' Responses to Likert Scale Items Key: F= Frequency; $(\%)$ = Percentage

The first attitude aspect measured the perceptions of the students on the importance of the course's evaluation in general. Findings in Table 7 indicate that 132 (70.6\%) participants strongly agreed, 29 (15.5\%) agreed, 4 (2.1\%) were undecided, $15(8.0 \%)$ disagreed and 7 (3.7\%) strongly disagreed with the item. Generally, the participants perceived the courses evaluation to be important with the highest mean score of 4.41 , which was above the average mean of 3.00 . The standard deviation (SD) was 1.11. This implies that they had a general positive attitude towards the aspect with minimum variation from the mean.

Aspect two of the attitudes measured whether AMUCTA students were always motivated to fill in the course's evaluation forms. 61 (31.9\%) students strongly agreed, 76 (39.8\%) agreed, 18 (9.4\%) were undecided, 27 (14.1\%) disagreed and $9(4.7 \%)$ strongly disagreed. More than two thirds $(71.7 \%)$ of the students were motivated to fill in the 
forms for the purpose of evaluating the courses and teaching at AMUCTA. Less than a quarter percent of the participants was not motivated. The results portray general positive attitudes towards the aspect with the mean score of 3.80 (SD $=$ 1.17), which is also above the average mean on the Likert scale.

The third attitudinal aspect measured whether AMUCTA students believed that all students should be involved in filling in courses evaluation forms at the college. 53 (27.7\%) students strongly agreed, 51 (26.7\%) agreed, 37 (19.4\%) were undecided, 26 (13.6\%) disagreed and 22 (11.5\%) strongly disagreed with the item. More than a half (54.4\%) of the students believed it was prudent that all students were involved in the course's evaluation process. This implies they had a positive attitude towards the aspect. Nevertheless, more than quarter percent $(25.1 \%)$ perceived it negatively since they believed that it was not good. It means they had a negative attitude towards the aspect. Less than a quarter percent was undecided. Generally, the students had positive attitudes with a mean attitude score of 3.46 and SD of 1.34 which was a slight increase in the variation from the mean attitude score.

The fourth attitude aspect was meant to determine whether courses evaluation improved teaching and learning at AMUCTA. 94 (49\%) strongly agreed, 37 (19.3\%) agreed, 24 (12.5\%) were not sure, 13 (6.8\%) disagreed and 24 (12.5\%) strongly agreed with the item. The results indicated a general positive attitude towards the aspect with a mean score of 3.85 that was a little higher than the average mean score of 3.0 and standard deviation of 1.41 .

The fifth attitude aspect determined on whether participants believed that courses evaluation improved quality assurance mechanism. 67 (34.9\%) strongly agreed, 53 (27.6\%) agreed, 32 (16.7\%) were undecided, 19 (9.9\%) disagreed and $17(8.9 \%)$ strongly disagreed. The mean score was 3.71 and the standard deviation was 1.29 . There was a positive attitude among participants in general on this attitudinal aspect. Generally, the students believed that courses evaluation improved quality assurance mechanism at AMUCTA.

The study further sought to find out whether students perceived the exercise of courses evaluation as useless. 31 $(14.6 \%)$ strongly agreed, 17 (9.0\%) agreed, 21 (11.1\%) were not sure, 37 (19.6\%) disagreed and 83 (43.9\%) strongly disagreed with the statement. The results indicated a mean score of 3.66 above the average and the standard deviation was 1.51 . The results meant that more than half percent (63.5\%) of the participants did not believe that courses evaluation was a useless exercise. Less than quarter percent $(23.6 \%)$ of participants perceived the exercise to be a waste of time. Hence, generally the students believed that the exercise was meaningful.

The seventh item determined whether the students felt that courses evaluation at AMUCTA was boring. 26 (13.9\%) strongly agreed, 22 (11.8\%) agreed, 21 (11.2\%) were undecided, 38 (20.3\%) disagreed and 80 (42.8\%) strongly disagreed with the statement. It means that the students were generally not bored by courses evaluation at the college as more than half percent (63.1\%) disagreed with the statement. About quarter percent (25.7\%) were bored by the exercise. The mean score was 3.66, which is above the average mean and standard deviation was 1.47.

Item eight measured whether the students saw courses evaluation at AMUCTA as a waste of time. 19 (9.9\%) strongly agreed, 18 (9.4\%) agreed, 25 (13.1\%) were indifferent, 42 (22\%) disagreed and 85 (45.5\%) strongly disagreed with the statement. The mean score of 3.83 was above the average mean with a standard deviation of 1.36 . More than two thirds percent $(67.5 \%)$ believed that courses evaluation was not a waste of time. Less than $20 \%$ perceived it to be a waste of time. This implies that there was generally a positive attitude towards courses evaluation among the students.

The ninth item focused on whether students perceived courses evaluation as being superficial. 27 (14.1\%) strongly agreed, 34 (17.8\%) agreed, 63 (33\%) were indifferent, 37 (19.4\%) disagreed and 27 (14.1\%) strongly disagreed with the statement. About a third (31.9\%) of the participants perceived the exercise to be superficial and about the same proportion (33.5) disagreed with the statement. The mean score was 3.02 and standard deviation 1.24. These are mixed findings. This could be attributed to the revelation that students saw no implementation of the results of courses evaluation; hence, they saw it to be superficial.

Item number ten focused on whether AMUCTA should stop courses evaluation by students. 19 (10\%) strongly agreed, 21 (11.1\%) agreed, 17 (8.9\%) were indifferent, 32 (16.8\%) disagreed and 101 (53.2\%) strongly disagreed with the statement with the mean score of 3.92 and the standard deviation of 1.40 . More than two thirds percent (70\%) believed that the courses evaluation was not superficial and less than quarter perceived it to be superficial. Hence, the findings indicated a positive attitude on maintaining courses evaluation at the university college.

In most of the items, the results were above the mean score. Generally, the participants had positive attitude towards courses evaluation and they perceived it to be important. However, as their participation rate in evaluation was low, then the attitude was not a factor but those factors raised by the participants. It can be argued that the issues raised for low response rate exerted more influence than their positive attitude towards the evaluation of courses, such that they did not partake in the evaluation exercise proportionately to their attitude. Presumably, the participation and response rate could have been higher if the concerns that hindered their response were decisively addressed. In the context of the fifty - fifty rule or theory, it can be said to be applicable as some students had negative attitude that influenced their participation in the course's evaluation exercise.

\subsection{Whether Courses Evaluation was Worthwhile}

Further investigation was done on whether students found the course evaluation exercise important at AMUCTA. 176 participants responded to the item. Among them, 130 (73.9\%) indicated that courses evaluation was important and about quarter percent $(26.1 \%)$ indicated that it was not important.

Those participants, who indicated that it was important explained that it was an effective strategy of ensuring quality of teaching and learning. One participant responded, 'It enables the management to know the situation of academic progress, the attitudes of students towards their lecturers and the relationship between students and lecturers'. Concurring with this view, another participant wrote, 'Course evaluation at AMUCTA is very important because it 
motivates the lecturers to work hard, follow course outline strictly, make presentations and seminars effectively and be punctual in their responsibilities'. Another one noted, 'It helps to improve academic performance through students' opinions towards their teachers, to know the performance of teachers in relation to whether they perform well or not and appropriate decisions can be made by the relevant management for maintaining the quality of education'. These mean that the participants had a clear knowledge of the relevance and importance of courses evaluation at AMUCTA.

However, some saw it as being unimportant and gave various reasons. They included their views not being considered, bias among students during evaluation and some students not willing to do it or not taking it seriously. One participant remarked, 'Because students evaluate teachers according to their personal interests but not according to the reality, only a few questionnaires are filled'. Yet another participant wrote, 'The University does not work upon the comments and opinions given by students during the evaluation. There is bias in evaluating teachers. Best (strict) teachers are given negative remarks because most students are lazy and do not like strict lecturers. Hence, the evaluation is just prejudiced and, so, not important'. Another one further noted, 'Students are not serious when filling in the evaluation forms. They just do it without serious consideration. So, they make wrong evaluation'. These are clear indicators that the courses evaluation at AMUCTA has challenges that students would want them addressed. Even though about three quarters of the participants saw course evaluation as an important exercise at AMUCTA, more than quarter percent saw it as insignificant for the said reasons.

The findings that revealed that the courses evaluations exercise was important reflect those of the other studies such as Sukdee, Tornee\&Kraipetch (2017), Okmen (2017) and Coetzee, Hoffmann and de Roubaix (2015). That it was not important provides another side of the findings; hence, becomes contrary to the positive findings noted and conveys mixed feelings on the results that are echoed by Chen, Wang \& Yang (2017) who established that the evaluation scores were correlated with students' grade and hence relative. Similar findings were reported by Archbong and Nja (2011), Flégl, Fortoul, Švec, Brand and Vizuet Ch. (2017) which indicated that participation in courses evaluation was determined by students' expectations in passes at final assessment and evaluation. Similar report on students' grades was revealed by Culver (2010. Therefore, the findings on courses evaluations are even controversial as Boggs (2008) noted.

This study also intended to determine whether the students believed that the courses evaluation at AMUCTA was effective and if they were satisfied with its practice. In this regard, participants were asked first to rate its effectiveness through four levels scale that ranged from not effective, partially effective, effective and very effective. The assumption was that students would have different levels of the effectiveness of courses evaluation practice at the university college. 173 participants responded to the item of the instrument. The findings are summarized in Table 8.

\begin{tabular}{|c|c|c|c|}
\hline \multicolumn{2}{|c|}{ Level of Effectiveness } & Frequency & Percent \\
\hline \multirow{4}{*}{} & not effective & 39 & 22.54 \\
\cline { 2 - 4 } & partially effective & 81 & 46.82 \\
\cline { 2 - 4 } & effective & 37 & 21.39 \\
\cline { 2 - 4 } & very effective & 16 & 9.25 \\
\cline { 2 - 4 } & Total & 173 & 100.0 \\
\hline
\end{tabular}

Table 8: Frequency Distribution of Responses on Levels of Effectiveness ( $N=173$ )

The findings in Table 8 indicate that less than quarter percent (22.54\%) of the participants rated the exercise as being not effective, more than a third percent $(46.82 \%)$ as partially effective, less than quarter percent $(21.39 \%)$ as effective and less than ten percent (9.25\%) rated it very effective. The scores on partially effective had the highest frequency, followed by partial effectiveness, effective and very effective respectively. Generally, the rating results showed that the students' perception on the effectiveness of courses evaluation did not commensurate to their expected level. It is an evidence that they saw it not working as earlier established.

One of the indicators of whether the students saw the courses evaluation practice worthwhile was their satisfaction with the practice. The study sought to find out whether students were satisfied by the course's evaluation at AMUCTA. It determined the levels of students' satisfaction with courses evaluation at the college. The assumption was that students would have different levels of satisfaction with the practice of courses evaluation at the college. Again, 173 participants responded to the item on the questionnaire. The findings are summarized in Table 9.

\begin{tabular}{|c|c|c|c|}
\hline \multicolumn{2}{|c|}{ Level of Satisfaction } & Frequency & Percent \\
\hline \multirow{4}{*}{} & not satisfied & 31 & 17.9 \\
\cline { 2 - 4 } & partially satisfied & 71 & 41.0 \\
\cline { 2 - 4 } & satisfied & 44 & 25.4 \\
\cline { 2 - 4 } & highly satisfied & 27 & 15.6 \\
\cline { 2 - 4 } & Total & 173 & 100.0 \\
\hline
\end{tabular}

Table 9: Frequency Distribution of Responses on Levels of Satisfaction ( $N=173)$

The findings in Table 9 indicate that less than quarter percent (17.9\%) participants were not satisfied with the practice of courses evaluation, more than a third percent (41\%) were partially satisfied, about a quarter percent $(25.4 \%)$ were satisfied and less than quarter percent (15.6\%) were highly satisfied.

These are mixed findings. The extreme levels of not being satisfied and highly satisfied got more or less a similar level of satisfaction of less than quarter percent but more than ten percent. Partial satisfaction had the highest scores 
followed by satisfied. In general, the students saw the satisfaction of courses evaluation wanting. This is inconsistent with its effectiveness. The reason for this may be why they retorted that its reports were not implemented; hence, they were not encouraged to actively partake in and respond to the evaluation forms. This accounted for their low rate of involvement in the exercise. However, to some of the students, it was not a hindrance.

The findings imply that the students saw the hygiene was not satisfactory on the performance of the evaluation of courses. By way of extension this could discourage them from actively partaking in the exercise; hence, it became a stumbling block to the participation in courses evaluation at AMUCTA. In this case, the theory of fifty - fifty applies. The aspect of students' satisfaction with the courses evaluation practice could be attributed to the management of the practice; hence, a factor of their low rate involvement in the exercise.

\subsection{Testing of Hypotheses}

The testing of hypotheses was meant to provide a deeper analysis of the data, determine the nature of the findings and allow generalization of the findings through inferential statistics to the population from which the sample was obtained. The following decision rule applied in all hypotheses: If $p$ value is $\leq 0.05$, we reject the null hypothesis $\left(H_{0}\right)$ but if $\mathrm{p}$ value is $>0.05$, we fail to reject the $H_{0}$. The first hypothesis sought to measure whether the students' program of study had influence on their rating of the effectiveness of courses evaluation at the AMUCTA. A four-level scale of not effective (1), partially effective (2), effective (3) and very effective (4) was used to generate the data.

The hypothesis tested was: There is a significant difference in the students' mean rating scores of the effectiveness of courses evaluation at AMUCTA based on their programmes of study. One-way Analysis of Variance (ANOVA) was used to test the hypothesis. It was presumed that the different programmes of study the participants belonged to would influence their rating of the effectiveness of courses evaluation. The basic assumption was that students' programme and subjects of specialization could respectively influence their views and rating of the effectiveness of courses evaluation. One of the reasons is the different teaching styles and relevance of the courses. This parametric model (ANOVA) was preferred to non-parametric tests as it is one of the robust tests that compares the means of more than two groups (Field, 2013). Assumptions of ANOVA include: approximate normal distribution of dependent variable, homogeneity /equality of variances of dependent variable groups, the samples have been randomly selected from the population and that dependent variable is either interval or ratio. The assumptions of normality and homogeneity were checked /tested. Tables 10 and 11 present summaries of the test results.

\begin{tabular}{|c|c|c|c|c|c|c|c|c|c|c|}
\hline \multicolumn{11}{|c|}{ Descriptive Results } \\
\hline \multicolumn{11}{|c|}{ Effectiveness Scores } \\
\hline & & \multirow[t]{2}{*}{$\mathrm{N}$} & \multirow[t]{2}{*}{ Mean } & \multirow[t]{2}{*}{$\begin{array}{c}\text { Std. } \\
\text { Deviation }\end{array}$} & \multirow[t]{2}{*}{$\begin{array}{l}\text { Std. } \\
\text { Error }\end{array}$} & \multicolumn{2}{|c|}{$\begin{array}{l}\text { 95\% Confidence } \\
\text { Interval for } \\
\text { Mean }\end{array}$} & \multirow[t]{2}{*}{ Minimum } & \multirow[t]{2}{*}{ Maximum } & \multirow[t]{2}{*}{$\begin{array}{l}\text { Between- } \\
\text { Component } \\
\text { Variance }\end{array}$} \\
\hline & & & & & & $\begin{array}{l}\text { Lower } \\
\text { Bound }\end{array}$ & $\begin{array}{l}\text { Upper } \\
\text { Bound }\end{array}$ & & & \\
\hline \multicolumn{2}{|c|}{ BAED } & 37 & 2.5135 & .90128 & .14817 & 2.2130 & 2.8140 & 1.00 & 4.00 & \\
\hline \multicolumn{2}{|c|}{ BEDSN } & 16 & 2.1250 & .95743 & .23936 & 1.6148 & 2.6352 & 1.00 & 4.00 & \\
\hline \multicolumn{2}{|c|}{ BUSUNESS } & 12 & 1.9167 & .90034 & .25990 & 1.3446 & 2.4887 & 1.00 & 3.00 & \\
\hline \multicolumn{2}{|c|}{ Total } & 65 & 2.3077 & .93413 & .11586 & 2.0762 & 2.5392 & 1.00 & 4.00 & \\
\hline \multirow[t]{2}{*}{ Model } & $\begin{array}{c}\text { Fixed } \\
\text { Effects }\end{array}$ & & & .91502 & .11349 & 2.0808 & 2.5346 & & & \\
\hline & $\begin{array}{c}\text { Random } \\
\text { Effects }\end{array}$ & & & & .19479 & 1.4696 & 3.1458 & & & .05986 \\
\hline
\end{tabular}

Table 10: Descriptive Test Results of Students' Satisfaction with Courses Evaluation

\begin{tabular}{|c|c|c|c|c|c|}
\hline \multicolumn{7}{|c|}{ ANOVA } \\
\hline & $\begin{array}{c}\text { Sum of } \\
\text { Squares }\end{array}$ & df & $\begin{array}{c}\text { Mean } \\
\text { Square }\end{array}$ & F & Sig. \\
\hline Between Groups & 3.936 & 2 & 1.968 & 2.351 & .104 \\
\hline Within Groups & 51.910 & 62 & .837 & & \\
\hline Total & 55.846 & 64 & & & \\
\hline
\end{tabular}

Table 11: One-Way ANOVA Test Results on Program Effects

The descriptive results in Table 10 show that the mean scores of participants were different. BAED participants' scores were the highest $(M=2.51)$ followed by BEDSN $(M=2.13)$ while BUSINESS mean scores $(M=1.92)$ being the lowest. However, one-way ANOVA test results in Table 11 indicate $F(2,62)=2.35, p=0.10$, which means it is greater than .05 level of significance. Hence, there is no significant difference in the mean scores between the groups. The difference in the descriptive statistic was by chance. Thus, we fail to reject the null hypothesis and conclude that there was no significant difference in the students' mean rating scores on the effectiveness of courses evaluation at AMUCTA based on programs. Therefore, the programs of study that students belonged to, had no significant influence on students' mean 
rating scores. It implies that the participants had more or less the same measure/levelling of effectiveness. So, the results mean that the students' rating was almost uniform and, therefore, more reliable.

The study compared the mean scores of students in BAED with those in BEDSN on their satisfaction with courses evaluation at the university college. Independent samples test (t-test) was used to measure the comparison as it is one of the robust models (tests) in comparing the means of two groups (Field, 2013). The tested hypothesis was: There is a significant difference in the BAED students' mean scores on their satisfaction with courses evaluation at AMUCTA when compared with those in BEDSN. The independent sample t-test was used to test the hypothesis.

The assumptions of t-test model are: That the subjects in two groups are randomly and independently selected; the variances of the dependent variables of the two samples are equal (homogeneous); the distribution of dependent variable is approximately normal; and, the scores in the two samples are either interval or ratio. The assumptions of homogeneity of variance and normality in distributions were checked. The test was computed by SPSS.The test results of the hypothesis are presented in Table 12.

\begin{tabular}{|c|c|c|c|c|c|c|c|c|c|c|}
\hline \multicolumn{11}{|c|}{ Independent Samples Test } \\
\hline & & \multicolumn{2}{|c|}{$\begin{array}{c}\text { Levene's } \\
\text { Test for } \\
\text { Equality of } \\
\text { Variances } \\
\end{array}$} & \multicolumn{7}{|c|}{ t-test for Equality of Means } \\
\hline & & \multirow[t]{2}{*}{$\mathbf{F}$} & \multirow[t]{2}{*}{ Sig. } & \multirow[t]{2}{*}{$\mathbf{t}$} & \multirow[t]{2}{*}{ df } & \multirow[t]{2}{*}{$\begin{array}{c}\text { Sig. } \\
(2- \\
\text { tailed) }\end{array}$} & \multirow[t]{2}{*}{$\begin{array}{c}\text { Mean } \\
\text { Difference }\end{array}$} & \multirow[t]{2}{*}{$\begin{array}{l}\text { Std. Error } \\
\text { Difference }\end{array}$} & \multicolumn{2}{|c|}{$\begin{array}{c}\text { 95\% Confidence } \\
\text { Interval of the } \\
\text { Difference }\end{array}$} \\
\hline & & & & & & & & & Lower & Upper \\
\hline \multirow[t]{2}{*}{$\begin{array}{l}\text { Satisfaction } \\
\text { with } \\
\text { evaluation }\end{array}$} & $\begin{array}{c}\text { Equal } \\
\text { variances } \\
\text { assumed }\end{array}$ & 1.664 & .201 & 1.435 & 66 & .156 & .39015 & .27186 & -.15264 & .93295 \\
\hline & $\begin{array}{c}\text { Equal } \\
\text { variances } \\
\text { not } \\
\text { assumed }\end{array}$ & & & 1.480 & 51.755 & .145 & .39015 & .26362 & -.13890 & .91920 \\
\hline
\end{tabular}

Table 12: Independent Samples T- Test between BAED and BEDSN Scores

Descriptive data indicated that the BEDSN students had higher mean scores $(M=2.89)$ than students from BAED $(\mathrm{M}=2.14)$. However, data in Table 12 the t-test results indicated no significant difference in the mean rating scores on students' satisfaction with courses evaluation at AMUCTA between the two groups $\mathrm{t}(66)=1.44, \mathrm{p}=.16$. Therefore, we fail to reject the null hypothesis and conclude that there was no significant difference in the mean rating scores on students' satisfaction with courses evaluation between BAED and BEDSN students at AMUCTA.

The t-test results imply that the students' variable of programme of study had no significant influence in their scores on their satisfaction with the evaluation of courses at AMUCTA. This gives the impression that the scores were stemming from the sample with the same experience and feelings.

The researcher was interested to find out whether students' age, program of study and sex had significant main effects on the mean rating scores on the effectiveness of courses evaluation at AMUCTA. A four-level scale of not effective (1), partially effective (2), effective (3) and very effective (4) was used to generate the scores. The numbers in the brackets were the respective scores assigned to the category of the responses from participants. Three-way ANOVA model was used to test the hypothesis. The same ANOVA assumptions were considered. The results are summarised in Table 13.

\begin{tabular}{|c|c|c|c|c|c|}
\hline \multicolumn{7}{|c|}{ Tests of Between-Subjects Effects } \\
\hline Source & $\begin{array}{c}\text { Type III Sum of } \\
\text { Squares }\end{array}$ & df & $\begin{array}{c}\text { Mean } \\
\text { Square }\end{array}$ & F & Sig. \\
\hline Corrected Model & $7.786^{\mathrm{a}}$ & 6 & 1.298 & 1.093 & .379 \\
\hline Intercept & 175.751 & 1 & 175.751 & 147.977 & .000 \\
\hline Age & .263 & 1 & .263 & .221 & .640 \\
\hline Program & 1.284 & 1 & 1.284 & 1.081 & .303 \\
\hline Sex & 1.488 & 1 & 1.488 & 1.253 & .268 \\
\hline Age * Program & 1.636 & 1 & 1.636 & 1.378 & .246 \\
\hline Age * Sex & 6.331 & 1 & 6.331 & 5.330 & .025 \\
\hline Program * Sex & .414 & 1 & .414 & .348 & .558 \\
\hline Age * Program * Sex & .000 & 0 &. &. &. \\
\hline Error & 62.948 & 53 & 1.188 & & \\
\hline Total & 466.000 & 60 & & & \\
\hline Corrected Total & 70.733 & 59 & & & \\
\hline \multicolumn{7}{|c|}{ a. R Squared = .110 (Adjusted R Squared = .009) } \\
\hline
\end{tabular}

Table 13: ANOVA Test Results on Students' Age, Sex and Program of Study and Scores 
The findings in Table 13 revealed that there was no significant main effect of age on the mean rating scores of students on the effectiveness of courses evaluation at AMUCTA, F $(1,53)=.22 ; p=.64$. Also, there was no significant effect of students' program of study on the mean rating scores on the effectiveness of courses evaluation at AMUCTA, F (1, 53) $=$ $1.08, \mathrm{p}=.30$. Further, there was no significant effect of sex on the students' mean rating scores on the effectiveness of courses evaluation at AMUCTA, $F(1,53)=1.25, p=.27$. Age and program of study as well as sex and program of study had no combined main effect on students' mean rating scores on the effectiveness of courses evaluation at AMUCTA, F $(1,53)=$ $1.38, \mathrm{p}=.25$ and $\mathrm{F}(1,53)=.35, \mathrm{P}=.56$ respectively. However, age and sex had significant combined effect on students' mean rating scores on the effectiveness of courses evaluation at AMUCTA, $F(1,53),=5.33, p=.03$. Students' characteristics of age and sex that had significant combined effects are echoed by scholars such as Thawabieh (2017) who found that age and gender had significant effects on evaluation scores. The two variables do influence students' perspectives, so they are important when evaluating learning and courses in higher learning institutions.

The study compared the students' mean scores on their satisfaction with courses evaluation between the Faculty of Education (FEDu) and the Faculty of Social Sciences (FASSc) using the independent samples $t$ - test. The tested hypothesis was: There is a significant difference in the students' mean rating scores on their satisfaction with courses evaluation at AMUCTA when comparing FEDu with FASSc. The same assumptions of $\mathrm{t}$ - tests applied. The results are summarized in Table 14.

\begin{tabular}{|c|c|c|c|c|c|c|c|c|c|c|}
\hline \multicolumn{11}{|c|}{ Independent Samples Test } \\
\hline & & \multicolumn{2}{|c|}{$\begin{array}{c}\text { Levene's } \\
\text { Test for } \\
\text { Equality of } \\
\text { Variances }\end{array}$} & \multicolumn{7}{|c|}{ t-test for Equality of Means } \\
\hline & & \multirow[t]{2}{*}{$\mathbf{F}$} & \multirow[t]{2}{*}{ Sig. } & \multirow[t]{2}{*}{$\mathbf{t}$} & \multirow[t]{2}{*}{ df } & \multirow[t]{2}{*}{$\begin{array}{l}\text { Sig. (2- } \\
\text { tailed) }\end{array}$} & \multirow[t]{2}{*}{$\begin{array}{c}\text { Mean } \\
\text { Difference }\end{array}$} & \multirow[t]{2}{*}{$\begin{array}{l}\text { Std. Error } \\
\text { Difference }\end{array}$} & \multicolumn{2}{|c|}{$\begin{array}{l}95 \% \text { Confidence } \\
\text { Interval of the } \\
\text { Difference }\end{array}$} \\
\hline & & & & & & & & & Lower & Upper \\
\hline \multirow[t]{2}{*}{$\begin{array}{c}\text { Scores on } \\
\text { satisfaction }\end{array}$} & $\begin{array}{c}\text { Equal } \\
\text { variances } \\
\text { assumed } \\
\end{array}$ & $\begin{array}{c}1.46 \\
3\end{array}$ & .231 & $\begin{array}{c}1.60 \\
3\end{array}$ & 66 & .114 & .47619 & .29698 & $\begin{array}{c}- \\
.1167 \\
4 \\
\end{array}$ & $\begin{array}{c}1.069 \\
12\end{array}$ \\
\hline & $\begin{array}{c}\text { Equal } \\
\text { variances } \\
\text { not } \\
\text { assumed }\end{array}$ & & & $\begin{array}{c}2.07 \\
8\end{array}$ & $\begin{array}{c}23.17 \\
9\end{array}$ & .049 & .47619 & .22916 & $\begin{array}{c}.0023 \\
4\end{array}$ & $\begin{array}{c}.9500 \\
4\end{array}$ \\
\hline
\end{tabular}

Table 14: Independent Samples T - Test Students' Scores Fedu between Fssc

The findings in descriptive statistics revealed that the descriptive mean scores of students in FEDu (M 2.16) was different from the scores of FSSc (M 2.74). The data in Table 14 on t-test results indicated that there was no significant difference in the mean rating scores between the two faculties $t(66),=1.60, p=.11$. This $p$ value is greater than the significance level of .05. The researcher failed to reject the null hypothesis and concluded that there was no significant difference in the mean rating scores on the students' satisfaction with courses evaluation at AMUCTA between the two faculties. Hence, the faculty to which the students belonged had no significant influence on the rating of satisfaction with the course's evaluation at the university college. The differences in descriptive statistics could be out of chance or random error.

\subsection{Courses Evaluation Strategies That Students Preferred to Evaluation Forms}

The participants were asked to suggest alternative strategies of monitoring teaching and learning at AMUCTA. They proposed various alternatives to evaluation forms. 142 participants responded to the questionnaire item. Table 15 presents a summary of the findings.

\begin{tabular}{|c|c|c|c|}
\hline S/No & Alternative & Frequency & Percent \\
\hline 1 & Use of College Baraza/Conference with students & 32 & 22.54 \\
\hline 2 & One course be taught by different lecturers & 7 & 4.93 \\
\hline 3 & Use of Suggestion Box & 32 & 22.54 \\
\hline 4 & Open discussion between lecturers and students & 6 & 4.23 \\
\hline 5 & The management to supervise teaching and learning & 19 & 13.38 \\
\hline 6 & To form courses evaluation committee of students and lecturers & 16 & 11.27 \\
\hline 7 & Use of OPRASS forms & 7 & 4.93 \\
\hline 8 & Use of evaluators from other colleges & 9 & 6.34 \\
\hline 9 & To supplement the evaluation with formative evaluation & 3 & 2.11 \\
\hline 10 & To be supervised by other lecturers not by course instructors & 11 & 7.75 \\
\hline & Total & 142 & 100 \\
\hline
\end{tabular}

Table 15: Alternative Courses Evaluation Strategies ( $N=142)$ 
The data in Table 15 indicate that out of the 142 participants, 32 (22.54\%) preferred the use of college baraza to evaluation forms. 7 (4.93\%) preferred that the courses be taught by different instructors, 32 (22.54\%) the use of a suggestion box, 6 (4.23\%) open discussion between lecturers and students and 19 (13.38\%) gave preference to supervision by the management rather than the use of the course's evaluation forms. Furthermore, $16(11.27 \%)$ preferred using evaluation committee to evaluation forms, 7 (4.93\%) the use of OPRAS forms and 9 (6.34\%) evaluation to be done by lecturers from other colleges. Finally, 3 (2.11\%) proposed to make it a continuous exercise like continuous assessment tests whereas $11(7.75 \%)$ suggested that the exercise should exclude the instructors from administering forms to students in the courses they teach themselves, preferring the exercise to be done by different lecturers for objectivity.

Forming an evaluation committee is echoed by scholars such as Leišytè and Westerheijden (2013), who reported that students were included in the evaluation committees and boards in universities in Europe. This can be organized by AMUCTAto ensure that courses evaluation go beyond the use of only the evaluation forms so as to diversify the sources of data on teaching and learning and enhance the effectiveness of quality assurance in the institution.

The use of College Baraza and open discussion between lectures and students as suggested by the participants, can be applied if it is well-organised. This is an open discussion approach in quality assurance mechanism. It has been proposed by scholars such as Ryan (2015) who noted that students can be part of the quality assurance panels for it to be more effective. As panels work in discursive manner, it can work in some cases to make courses evaluation more effective instead of solely relying on the evaluation forms.

Some participants proposed that AMUCTA should retain courses evaluation through filling in evaluation forms. However, they suggested that this can still be effective if only the whole process of using the courses evaluation forms could be improved by the institution. 104 participants responded to the item on the questionnaire. The findings are presents in Table 16.

\begin{tabular}{|c|c|c|c|}
\hline S/No & Suggestions & Frequency & Percent \\
\hline 1 & Enhancing awareness to students on the importance of filling in the forms & 39 & 37.5 \\
\hline 2 & Use of simple language in the course's evaluation form & 8 & 7.69 \\
\hline 3 & All students to be involved in the course's evaluation exercise & 5 & 4.81 \\
\hline 4 & The format of the course's evaluation form contains multiple choice items \\
only & 13 & 12.5 \\
\hline 5 & The management, not the instructors, to conduct the exercise of \\
& administering the evaluation forms. & 9 & 8.65 \\
\hline 6 & Administration of the course evaluation forms be done outside lecture hours & 11 & 10.58 \\
\hline 7 & Evaluation be done on formative basis, not at the end of the course/semester. & 19 & 18.27 \\
\hline & Total & 104 & 100 \\
\hline
\end{tabular}

Table 16: Suggestions for Improving Courses Evaluation at AMUCTA ( $=104)$

Data in Table 16 show that 39 (37.5\%) participants suggested that AMUCTA should raise awareness among the students on the importance of taking part in courses evaluation and 8 (7.69\%) pointed out that the language that was used in the evaluation forms be made simple and clear to students. Five (4.81\%) participants proposed that all students should be involved in the evaluation exercise for validity purposes instead of sampling a few for the exercise. Thirteen (12.5\%) proposed the use of multiple-choice items in the evaluation form. Nine (8.65\%) participants suggested that the management should conduct the evaluation exercise instead of lecturers themselves doing it. Eleven (10.58\%) suggested that the course evaluation exercise should be conducted outside the lecture hours. Lastly, nineteen (18.27\%) participants proposed that AMUCTA should make the evaluation exercise a continuous process just like the continuous assessment tests in the teaching and learning. Additionally, one participant wrote:

The top-level management should engage in conducting surveys by entering into classes during lectures so as to know the challenges that students face. All courses evaluation forms should be in Kiswahili to enable students to express articulately their opinions, the challenges they face and suggestions to tackle the challenges. The courses should be in open ended form so that students can express their feelings than the use of closed ended questions.

Yet, another participant remarked:

When lecturers administer the evaluation forms to students, this sometimes causes fear among the students and this affects the way they rate the lecturer being assessed. So, it is better for the administrators to use different alternative methods such as coming to class themselves to see how and what the lecturers teach and therefore do the evaluation themselves without involving students.

Furthermore, another participant retorted, 'Courses evaluation must be done by the college management and not students'. Concurring with this view, another one wrote, 'Course evaluation should not involve the course instructor and it should be a formative and summative exercise'. Yet, another participant wrote, 'Lecturers should be evaluated by other people from outside the college'.

Some findings such as the suggestion to adopt formative evaluation are echoed by other scholars. Gravestock and Gregor-Greenleaf (2008) argued that evaluation of courses should include formative form such as mid-semester course evaluations. McConnell and Doolittle (2012) articulated that providing feedback on faculty teaching at any point during the semester would be more meaningful than the traditional summative courses evaluation exercise. The views of participants have research backing and could be taken into consideration for improving courses evaluation at universities. They may be employed to enhance courses evaluations at AMUCTA. Thus, from these findings, it is imperative to acknowledge that the participants provided viable alternative systems of courses evaluation at the university college. 
Baleni (2015) confirmed that formative assessment is effective and that it scales up the students' commitment to learning. Peterson (2016) recommended formative evaluation as it provides immediate feedback and offers the opportunity for improving the teaching/learning of different courses. Similarly, Nyabero (2016) noted that students can be involved in formative evaluation of courses.

Creating awareness and encouraging students to actively take part in evaluation of courses is viable. These have been seen to work in scaling up the rate of students' response to courses evaluation as reported by Chapman and Joines (2917). Since students are the most reliable source of evaluation (Archibong and Nja, 2011), they should be made to play their noble role effectively. If both the instructors and students play their roles effectively, a meaningful courses evaluation can be realised (Kahramanoglu, Aslan, Yilmaz, Odabas, Tekerek and Oflaz, 2018). The instructors should encourage students to make objective evaluation of their courses in order to improve teaching and learning processes.

Creating awareness to students on the importance of taking part in courses evaluation has been proven to be effective. This could include some giving some motivations as recommended by scholars. For instance, Leišyte and Westerheijden (2013) reported that students' response rates are often low and their opinions are seen as mere tokens; hence, they recommended that higher institutions of learning should device strategies to motivate those students who participate in evaluating the courses or teaching and learning. They urged the institutions to make prompt feedback to students and convince them that they take their opinions seriously so as to encourage them to take part in the evaluation of education issues in their institutions. This is taken as an effective means of improving their involvement in courses evaluation and quality assurance.

A similar view was reported by Darwin (2016) who found that the academics staff perceived involving of students in courses evaluation as a mechanical exercise of quality assurance mechanism on their work while students' participation was at a low rate (35\%). The students' low participation rate was attributed to the diminished levels of encouragement to participate in the exercise by program leaders. This implies that motivation is important to both the students and instructors to make the exercise more effective. Otherwise the challenges that are related to it might hamper its functioning. Grayson (2012) noted that evaluation in higher education institutions is helpful and helps in making judgments of merit or worth about a program, service, policy or whatever is being evaluated. Though careful and rigorous professional evaluation is valuable for making informed decisions, it is, however, quite demanding, costly and timeconsuming. In this view, Edwards (2018) recommended encouragement of students to informally provide comments and raise issues or concerns for improving teaching and learning. It is, therefore, important for AMUCTA to device strategies of encouraging students to contribute to quality assurance mechanism by actively evaluating courses offered at the university college.

\section{Conclusions and Recommendations}

The conclusions have been drawn based on the research questions while the recommendations are made on some aspects of the key findings and the possible areas for further study.

\subsection{Conclusions}

The study concludes that the students had concerns that made them lose interest in actively participating in courses evaluation at AMUCTA. The driving forces of the low rate of participation were from the environment of AMUCTA rather than from the students. They stemmed from the AMUCTA management (not giving feedback to students on courses evaluations reports and the poor timing of the evaluations exercise), instructors' characteristics of being a threat to students, the questions that were too many in the evaluation forms and the difficult language used in the forms which was problematic to some students. Furthermore, there was also a language (English) barrier on the part of some students whose level of competence was low.

Notwithstanding the noted hindrances, the students had positive attitudes towards courses evaluation and saw it as a worthwhile mechanism for ensuring quality education at AMUCTA. However, the unfavourable circumstances at the university college hampered them from actively participating in the evaluation of courses. Theoretically, the participants saw the evaluation of courses as important but they were discouraged by the outcome of evaluations which were never made known to them. Hence, in practice, they saw it as a waste of time in this regard. Generally, there were no significant relationships between students' scores on the effectiveness and satisfaction with courses evaluation and their demographic characteristics. The proposed alternatives of courses evaluation were relevant and viable.

\subsection{Recommendations}

The study recommends that the AMUCTA management should work on the opinions and suggestions of the students raised on courses evaluation in this study. It also recommends that the university management should devise ways of encouraging the students to take the evaluation of courses seriously; hence, make them to play their part actively to enhance meaningful self - assessment at AMUCTA. The instructors of the courses need to ensure that the classes are friendly between them and students so as to ensure democracy in education and enable the students to make free and informed evaluation of the courses for effective and efficient self - assessment mechanism at AMUCTA.

Further studies can be carried on the following aspects:

- Instructors' views on courses evaluation at AMUCTA

- How to align students' suggestions on improving courses evaluation with the SAUT/AMUCTA policy of evaluation of courses.

- Whether AMUCTA management is committed on self - evaluation through students' evaluation of courses. 


\section{References}

i. Adair J. (2006). Leadership and Motivation: The Fifty-Fifty Rule and the Eight key Principles of Motivating Others. London: Kogan Page Limited

ii. Al-Ali S. (2014). Are lecturers transferring the necessary skills needed for the workplace? The College of Technological Studies, Kuwait - A Case study. Journal of International Education and Leadership. 4(2), 1 - 9: Retrieved from: http://www.jielusa.org/

iii. AMUCTA (2016). Report on Courses Evaluation for First Semester 2015/2016 Academic Year Quality Assurance Office

iv. AMUCTA (2017). Students' Course Evaluation Report: BAED and BEDSN Programs - First Semester 2016/2017. Quality Assurance Office

v. AMUCTA (2019). Report on Courses Evaluation for First Semester 2018/2019 Academic Year Quality Assurance Office

vi. Archibong, I.A. and Nja, M.E. (2011). Towards improved teaching effectiveness in Nigerian Public Universities: Instrument design and validation. Higher Education Studies (1)2, 78 -91doi:10.5539/hes. v1n2p78

vii. Atek, E. S. E., Salim, H. S., Halim, Z. A., Jusoh, Z. \& Yusuf, M.A. M (2015). Lecturer's gender and their valuation of student evaluation of teaching. International Education Studies; (8)6, 132 - 141: doi:10.5539/ies.v8n6p132

viii. Babbie, E. (2008). The Basics of Social Research (4th Ed.). Belmont: Thomson Learn-ing

ix. Baleni Z. (2015). Online formative assessment in higher education: Its pros and cons' The Electronic Journal of e-Learning 13(4), 228-236; retrieved from www.ejel.orgon 17/12/2019

x. Celebi M. (2018).'To Use or Not to Use-That Is the Question!' Using Facebook as an Educational Tool in Recreational Leadership Course. Journal of Education and Training Studies. 6(7), 94 - 107; doi:10.11114/jets.v6i7.3302

xi. Chapman D.D and Joines J.A. (2017). Strategies for increasing response rates for online end-of-course evaluations. International Journal of Teaching and Learning in Higher Education. 29(1), 47-60 http://www.isetl.org/ijtlhe/ ISSN 1812-9129

xii. Chen C. Y., Wang S. Y. \& Yi-Fang Yang Y. (2017). A Study of the correlation of the improvement of teaching evaluation scores based on student performance grades. International Journal of Higher Education 6(2), 162 168. doi:10.5430/ijhe.v6n2p162

xiii. Coetzee T., Hoffmann W.A. and de Roubaix M. (2015). An Evaluation of Research Ethics in Undergraduate Health Science Research Methodology Programs at a South African University: Journal of Empirical Research on Human Research Ethics: An International Journal, 10(4), 389-394; URL: https://www.jstor.org/stable/10.2307/90012092

xiv. Coyne, R.D., Lee, J. and Petrova, D. (2017). Re-visiting the flipped classroom in a design context. Journal of Learning Design (10)2, 1 - 13

xv. Culver S. (2010). Course Grades, Quality of Student Engagement and Students' Evaluation of Instructor. International Journal of Teaching and Learning in Higher Education, 22(3), 331-336 Retrieved from: http://www.isetl.org/ijtlhe/ ISSN 1812-9129 on 12/12/2019

xvi. Darwin S. (2016). Student Evaluation in Higher Education: Reconceptualising the Student Voice Springer International Publishing Switzerland. DOI 10.1007/978-3-319-41893-3

xvii. Edwards W.L. (2018) Seeking excellence in higher education teaching: Challenges and reflections: 9th International Conference on University Learning and Teaching: 'Revolutionising Education: Challenges, Innovation and Collaboration' 28-29 November, Concorde Hotel, Shah Alam

xviii. Flégl M., Fortoul O. M. B., Švec V., Brand B. J., Vizuet Ch. (2017). Analysis of professors' evaluation at La Salle University México from 2010 to 2016: What the results indicate?'Journal on Efficiency and Responsibility in Education and Science, 10(3), 76 - 85. doi: 10.7160/eriesj.2017.100303

xix. Fraile R. and Bosch-Morell F. (July 2015). Considering teaching history and calculating confidence intervals in student evaluations of teaching quality: An approach based on Bayesian inference Higher Education, 70(1) 5572. URL: https://www.jstor.org/stable/43648853Accessed: 18-12-2019 11:41 UTC

xx. Gall, M.D, Gall, J.P. and Borg, W.R. (2007). Educational Research: An Introduction (8 ${ }^{\text {th }}$ Ed.). Boston: Pearson Education, Inc.

xxi. Grayson T.E. (2012). Approaches to Evaluation in Higher Education in Secolsky E. C. and Denison D.B. (Eds) Handbook on Measurement, Assessment, and Evaluation in Higher Education. pp. 455 - 456, New York: Routledge

xxii. Gravestock P, Gregor-Greenleaf E. (2008). Student Course Evaluations: Research Models and Trends. Toronto: Higher Education Quality Council of Ontario

xxiii. Gravestock P, Greenleaf E. and Boggs A.M (2008).The Validity of Student Course Evaluations: An Eternal Debate? A Conference Paper, based on a session given at Society for Teaching and Learning in Higher Education (STLHE) at the University of Windsor, in 'Collected Essays on Teaching and Learning' Vol. II pp. 152 - 157 Retreated from: https://files.eric.ed.gov/fulltext/EJ1057169.pdf on 12/12/2019

xxiv. Groen, J.F. \& Herry, Y. (2017). The Online Evaluation of Courses: Impact on Participation Rates and Evaluation Scores. Canadian Journal of Higher Education, 47(2), 106 - 120

xxv. Guder F. and Malliaris M. (2013). Online Course Evaluations Response Rates. American Journal of Business Education 6(3),333 - 338 
xxvi. Husbands C. T. (1997), Variations in students' evaluations of teachers' lecturing in different courses on which they lecture: A Study at the London School of Economics and Political Science Higher Education, 33(1), 51-70; URL: https://www.jstor.org/stable/3448312. Accessed: 18-12- 2019 11:47 UTC

xxvii. Imansari N. and Sutadji, E. (2017). A Conceptual framework curriculum evaluation electrical engineering education. International Journal of Evaluation and Research in Education (IJERE)(6)4, 265 - 269

xxviii. Jiang Y.H., Javaad S.S., golab L. (2016). Data Mining of Undergraduate Course Evaluations Informatics in Education 15(1), 85-102; DOI: 10.15388/infedu.2016.05

xxix. Johnson M.D., Narayanan A., and Sawaya W. J. (2013). Effects of course and instructor characteristics on student evaluation of teaching across a College of Engineering. Journal of Engineering Education. 102(2), 289318: DOI 10.1002/jee.20013

xxx. Kahramanoglu R., Aslan E., Yilmaz 1.D., Odabas C., Tekerek S and Oflaz O. (2019). Identifying the Target Needs of Preparatory Classes for Undergraduate Programs in Foreign Languages: A Case Study of the Engineering Departments. Journal of Education and Training Studies7 (2), 14 - 23. doi:10.11114/jets.v7i2.3676

xxxi. Kombo, D. K and Tromp, D.L.A. (2006). Proposal and Thesis Writing: An Introduction. Nairobi: Paulines Publications Africa

xxxii. Leišytė L., Westerheijden D.F. (2013). Students as Stakeholders in Quality Assurance in eight European Countries. Research on Quality of Higher Education, pp.13 - 27 Retrieved from: http://dx.doi.org/10.7720/1822-1645.10.1

xxxiii. McConnell K.D. and Doolittle P.E.(2012).Classroom-level Assessment: Aligning Pedagogical Practices to Enhance Student Learning in Secolsky E. C. and Denison D.B. (Eds). Handbook on Measurement, Assessment, and Evaluation in Higher Education. pp.15 - 30 New York: Routledge

xxxiv. Mudavanhu, Y. (2015). Differences in perceptions of the importance of subject matter knowledge and how these shaped supervision and assessment of student teachers on teaching practice. Journal of Education and Training Studies. 3(1), 98 - 107; doi:10.11114/jets.v3i1.589

xxxv. Mugenda, O.M and Mugenda, A. G. (2003). Research Methods: Quantitative \& Qualitative Approaches (Revised Edition), Nairobi: Acts Press

xxxvi. Nabaho, L., Aguti, J. N., \&Oonyu, J. (2017). Making sense of an elusive concept: Academics' perspectives of quality in higher education. Higher Learning Research Communications, 7(2), $1 \quad-\quad 16$. http://dx.doi.org/10.18870/hlrc.v7i2.383

xxxvii. Njoku A. (2018). Teaching Health Disparities Awareness in Undergraduate Public Health Courses IJ-SoTL. 12(2), Art. 15, 1 - 8https://doi.org/10.20429/ijsotl.2018.120215

xxxviii. Nyabero C. (2016). Toward a collective approach to course evaluation in durriculum Development, A Contemporary perspective. Journal of Education and Practice (Online) 7(35), 60 - 64. www.iiste.org

xxxix. Okmen, A.S. (2017). Evaluation of the physical education and sports curriculum in Turkish schools. Educational Research and Reviews.12(16), 811-816 DOI: 10.5897/ERR2017.3303

xl. Peterson J. L. (2016). Formative Evaluations in Online Classes. The Journal of Educators Online-JEO 13(1), 1 - 24

xli. Ratanapruks, A. (2015). The Description and Evaluation of Listening on a Thai University Fundamental English Course: A Case Study (Volume I) PhD thesis: University of Essex

xlii. Royal K. D. \& Stockdale M. R. (2015). Are Teacher Course Evaluations Biased Against Faculty That Teach Quantitative Methods Courses? International Journal of Higher Education. 4(1), $217-224$. doi:10.5430/ijhe.v4n1p217

xliii. Rovoi, A.P.; Ponton, M.K; and Baker, J.D. (2013). Social Science Research Design and Statistics. A Practitioner's Guide for Research Methods and SPSS Analysis. Chesapeake: Watertree Press LLC

xliv. Ryan, P. (2015). Quality assurance in higher education: A review of literature. Higher Learning Research Communications, 5(4), 1 - 12. http://dx.doi.org/10.18870/hlrc.v5i4.257

xlv. SAUT (2017). Quality Assurance Manual, Mwanza: Quality Assurance Directorate Seechaliao T. (2015). Lecturers' experience of using social media In higher education courses Contemporary issues in Education Research - 4th Quarter, 8(4), 215 - 222

xlvi. Sukdee,T., Tornee, S. \& Kraipetch, C. (2017). Factor analysis of key success indicators in curriculum quality assurance operation for bachelor's degree in physical education. International Journal of Higher Education (6)3, 109 - 115: doi:10.5430/ijhe.v6n3p109

xlvii. TCU (2014). Quality Assurance General Guidelines and Minimum Standards for Provision of University Education in Tanzania (2nd Ed.). Dar es Salaam

xlviii. Thawabieh, A.M. (2017). Students Evaluation of Faculty. International Education Studies; 10(2), doi:10.5539/ies.v10n2p35 URL: http://dx.doi.org/10.5539/ies.v10n2p35

xlix. Turley C. and Graham C. (2919). Interaction, Student Satisfaction, and Teacher Time Investment in Online High School Courses. Journal of Online Learning Research.5(2), 169-198

l. URT (2013).The Universities Act (CAP. 346) The Universities (General) Regulations, Arrangement of Regulations

li. Yin Fah, B.C.; and Osman, S. (2011). A Case Study of Student Evaluation of Teaching in University. International Education Studies (4)1, 44 - 50; www.ccsenet.org/ies

lii. Zhao J. \& Gallant D. J. (2012). Student evaluation of instruction in higher education: exploring issues of validity and reliability, Assessment \& Evaluation in Higher Education, 37(2), 227- 235, DOI: $10.1080 / 02602938.2010 .523819$ 